\title{
Utilization of Ozone and Composite Materials in the Seed Treatment to Stimulate the Germination and Growth of Agricultural Crops
}

\author{
ALISA MOSNEAGA ${ }^{1}$, VALENTIN NEDEFF ${ }^{2,3}$, ION SANDU ${ }^{4,5}$, PETRU LOZOVANU ${ }^{1}$, \\ EMILIAN MOSNEGUTU ${ }^{2 *}$, MIRELA PANAINTE LEHADUS ${ }^{2 *}$, IOAN GABRIEL SANDU ${ }^{6,7 *}$ \\ ${ }^{1}$ Romania 1State University of Moldova, 60 Mateevici, MD-2009, Chisinau, Moldova \\ ${ }^{2}$ Vasile Alecsandri University of Bacau, Faculty of Engineering, 157 Calea Marasesti, 600115, Bacau, Romania \\ ${ }^{3}$ Gheorghe Ionescu Sisesti, Academy of Agricultural and Forestry Sciences Bucharest, 61 Marasti Str., 011464, \\ Bucharest, Romania \\ ${ }^{4}$ Alexandru Ioan Cuza University of Iasi, Arheoinvest Interdisciplinary Platform, Scientific Investigation Laboratory, 11 \\ Carol I Blvd., 700506, Iasi, Romania \\ ${ }^{5}$ National Institute for Research and Development in Environmental Protection, 294 Splaiul Independentei Blvd., \\ 060031, Bucharest, Romania \\ ${ }^{6}$ Gheorghe Asachi Technical University of Iasi, Materials Science and Engineering Faculty, 53A D. Mangeron Blvd., \\ 700050, Iasi, Romania \\ ${ }^{7}$ Romanian Inventors Forum, 3 Sf. Petru Movila Str., Bloc L11, III/3, 700089, Iasi, Romania
}

\begin{abstract}
In the work are presented the results of research on the influence of biostimulation treatment of three agricultural species, namely wheat (Triticum aestivum L.), corn (Zea mays L.) and beans (Phaseolus vulgaris L.). Biostimulation of agricultural species consists of a pretreatment with ozonated water with concentration $1.3 \mathrm{mg} / \mathrm{L}$ and deposition on the surface of the seeds of a layer with thickness $0.3 \div 0.5 \mathrm{~mm}$ composite material consisting of a clay solution with carbon clusters. The study showed that the seeds subjected to treatment have a higher germination energy for all samples compared to the control ones. Also, treatment with composite materials induced an obvious stimulation of growth, which led to increased growth rates of plants, in particular, by $41.17 \%$ for wheat, by $18.46 \%$ for corn and by $29.5 \%$ for beans, compared to control samples, measured 10 days after planting. The application of ozone treatment on seeds increased the growth rate by $16.19 \%$ for beans, by $26.08 \%$ for wheat and only by $2.97 \%$ for corn.
\end{abstract}

Keywords: ozone, composite material, germination, growth stimulation

One of the prospects for the development of effective agriculture, it is deemed the programed action to certain physico-chemical factors on the environment for the growth of crops at different stages of development, in order to change the state of energy in order to stimulate the process of germination of seeds and growth of plants, increase their resistance to the influence of the external factors and the increase in their productivity [1-18]. Lately, an alternative in agriculture to stimulate the processes of agricultural development and harvesting of pure organic products is the use of physico-chemical methods. It has been established that ozone has unique antibacterial properties, ecological and safe for the environment, influences the microflora and increases the yield of plants [18-35].

The chemical composition of seeds is of practical importance, since the quantity and properties of the Constituent substances is the basis of quality and nutritional value, which largely depends on the preparation of seeds for sowing. Treatment of seeds with ozone in gaseous state or in the form of a solution with a low percentage of ozone content corresponding to each crop has a complex effect on the seeds. As a result of the treatment, germination energy increases, agricultural production and toxic by-products are not formed [24].

For the growth and development of plants are especially responsible regulators- phytohormones, the meaning of which is the chemical start of plant phenophases. Five groups of phytohormones are known: auxins, cytokinin's, giberereline, abscisic acid and ethylene $[25,26]$. The interaction of ozone with plant phytohormones is an important process, since these substances act in very small quantities and can be freely inactivated by ozone [24]. For these reasons, ozone treatment of agricultural crop seeds requires the determination of the treatment method, treatment duration and ozone concentration limits for each crop separately.

The present study investigated the effects of a biostimulation treatment on the seeds of three species of agricultural crops: wheat (Triticum aestivum L.), corn (Zea mays L.) and beans (Phaseolus vulgaris L.), on germination and growth. Biostimulation consists of pretreatment of seeds with composite material-clay and carbon clusters and treatment with ozonated water.

*email:emos@ub.ro; mirelap@ub.ro; gisandu@yahoo.com 


\section{Experimental part}

Water ozonation

The preparation of ozonated water was carried out by electrochemical method. Therefore, oxygen at low pressure was passed through a quartz tube in which two electrodes connected at a voltage of $10 \mathrm{kV}$ were installed. The ozone concentration was determined by the oxygen flow at the entrance to the tube, and the oxygen-ozone mixture was subsequently dissolved in water. To determine the concentration of ozone was used spectrophotometric method. The calibration of the plant was carried out by the iodometric method of determining the concentration of ozone dissolved in water [36]. In the paper, ozonated water with ozone concentration within $1.3 \mathrm{mg} / \mathrm{L}$. was used for treatment.

\section{Preparation of composite material with clay and carbon clusters}

The composite material was prepared based on clay containing $3 \%$ carbon clusters. The primary substance, the carbon clusters, was obtained by burning the pure spectral graphite in the voltaic arc in the helium atmosphere at the pressure of 50-100 torr [37]. The content of clusters of different order was determined by helium pressure, the rate of decomposition of graphite electrodes and the voltage in the arc. For qualitative determinations of carbon clusters was used mass spectrometric method. The content of carbon clusters in significant quantities were of the order $\mathrm{C}_{56}, \mathrm{C}_{50}$, $\mathrm{C}_{44}, \mathrm{C}_{32}, \mathrm{C}_{28}, \mathrm{C}_{24}$.

The clay used in the work was collected from an unpolluted area of massive, uniformly colored layers.

The evaluation of the composition of the clay sample was carried out by X-ray diffraction. According to the powder diffraction pattern it was found that the sample shows the clear presence of $\mathrm{SiO}_{2}(56,33-79,89 \%$ the size of the particles $>0.01 \mathrm{~mm})$, and traces of $\mathrm{Na}_{2} \mathrm{SO}_{4}, \mathrm{Fe}_{2} \mathrm{O}_{3}, \mathrm{Al}_{6} \mathrm{SiO}_{13}, \mathrm{MgSiO}_{2},(\mathrm{Ca}, \mathrm{Na})(\mathrm{SiAl}){ }_{4} \mathrm{O}_{8}$ etc. [38].

Initially the clay was dissolved in water, and then separated from the content of undissolved particles. After the deposition of clay in the precipitate, the samples were left in the open air until complete dehydration and then dispersed to micronic sizes. The composite material was obtained from clay dust mechanically mixed with carbon clusters.

The mixture obtained by clay and carbon clusters was deposited in a thin layer of $0.3 \div 0.5 \mathrm{~mm}$ on the surface of the seeds.

\section{Seed preparation}

The seeds were chosen as representative species of culture, for their investigation in terms of germination and growth at the first stage of development. For treatment were selected groups of 20 seeds of each species. Before undergoing treatment, the seeds were kept in a closed, electrically shielded enclosure for 24 hours at a relative humidity of $35 \%$ and a temperature of $18^{\circ} \mathrm{C}$.

For ozonation, the seeds, in a thin layer, were placed in a pot in which ozonated water was located. Next, the vessel was placed in an enclosure, where it was kept for 20 minutes for each batch.

The deposition of the clay layer with carbon clusters of $0.3 \div 0.5 \mathrm{~mm}$ on the surface of the seeds was carried out by moistening them, then spraying the dust mixture.

\section{Results and discussions}

Seed germination is a phenomenon of nature, the physiological and bio-chemical complex that are involved in several biological factors that act on the embryo [31]. An important tool for indicating the performance of a seed batch is the precise quantification of germination by accurate analysis of the cumulated germination data. These indices make it possible to assess the potential protective function of a developing plant organism [38-41].

The germination parameters were determined in the following way [38-41]:

-germination capacity (FGP), were FGP represents the total number of seeds that germinated at the end of the investigation in relation to the initial seed number $\mathrm{x} 100$.

-Germination rate index (GRI), with:

$$
G R I=(G R I)=G 1 / 1+G 2 / 2+\ldots .+G_{i} / i,
$$

where $\mathrm{G}_{\mathrm{i}}$ is the percentage of germination on day $\mathrm{i}$.

average germination time (MGT), with:

$$
M G T=\frac{\sum_{i=1}^{k} G_{i} t_{i}}{\sum_{i=1}^{k} G_{i}}
$$

where, $t_{i}$ is the time from the beginning of the tests to the time $I, G_{i}$ the number of seeds germinated at the time $t_{i}$. 
In figure 1 is represented the final germination rate of seeds of Triticum aestivum L., Zea mays L. and Phaseolus vulgaris $\mathrm{L}$. depending on the way of batch processing.

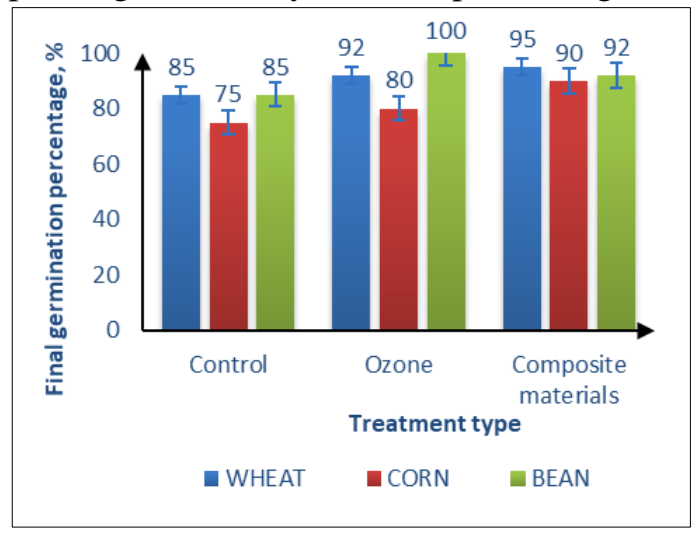

Fig. 1. Final germination percentage of seeds

Figure 1 shows that on the studied variants, the maximum germination rate was reached by the seeds of Phaseolus vulgaris L., processed with ozone, and the lowest rate, 75\%, was obtained by the seeds of Zea mays L. from the control batch. The results clearly indicate that each plant species reacts differently to stimulating factors.

Maximum germination compared to control samples for bean seeds subjected to ozonized water treatment proved to be $15 \%$ higher and compared to batch processed with composite material by $8 \%$. The maximum rate of the batches processed with composite material consists of: for wheat $95 \%$, exceeding by $10 \%$ the control batch and only by $3 \%$ the batch treated with ozonated water; for corn $90 \%$, by $15 \%$ more than the control batch and by $10 \%$ compared to the group treated with ozonated water; for beans $92 \%$, by $7 \%$ more than the control batch and by $8 \%$ less than the group treated with ozonated water. As we know, seed germination provides a suitable basis for the growth, development and yield of plants.

In figure 2 is represented the average germination time of seeds as a function of the treatment conditions.

The average germination time is a measure of the rate of germination and the temporal spread of germination. Thus, we determined the number of seeds germinated on the first day, and the total number of germinated seeds in the ninth day, considering the number of viable seeds germinated.

As can be seen from the graph (Fig. 2) ozone contributed to an early development of seeds of Phaseolus vulgaris L. and Triticum aestivum L. at $36 \mathrm{~h}$. In relation to the batches treated with the composite material was observed, a value of MGT less during the first $48 \mathrm{~h}$ compared to the other samples, however, since the $60 \mathrm{~h}$ has been registered indicators that are higher than the control seeds, beans, and corn.

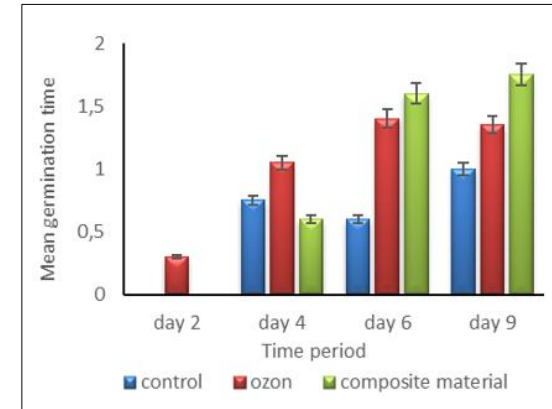

a)

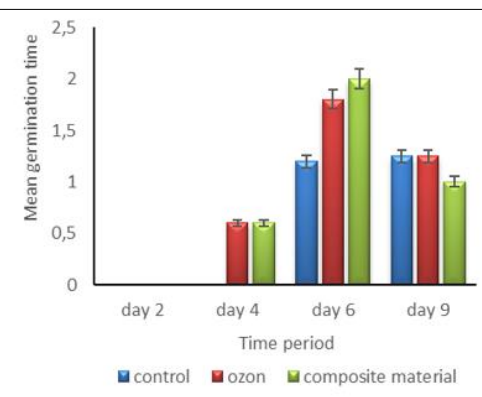

b)

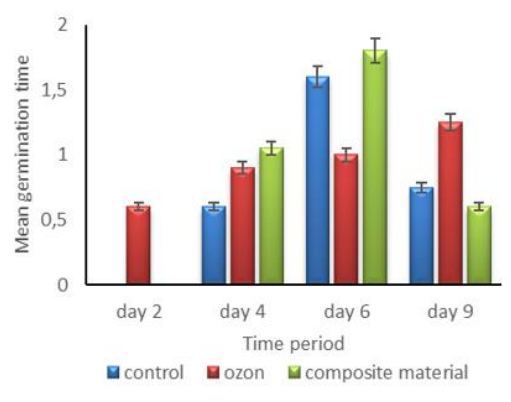

c)

Fig. 2. Mean germination time for: a) Triticum aestivum L., b) Zea mays L. and c) Phaseolus vulgaris L seeds 
Another parameter analyzed was the germination rate index (GRI), which reflects the seed germination speed, but also the seedling vigor by the appearance of the radicle. In figure 3 is represented the GI variation of seeds depending on the specifics of batch processing.

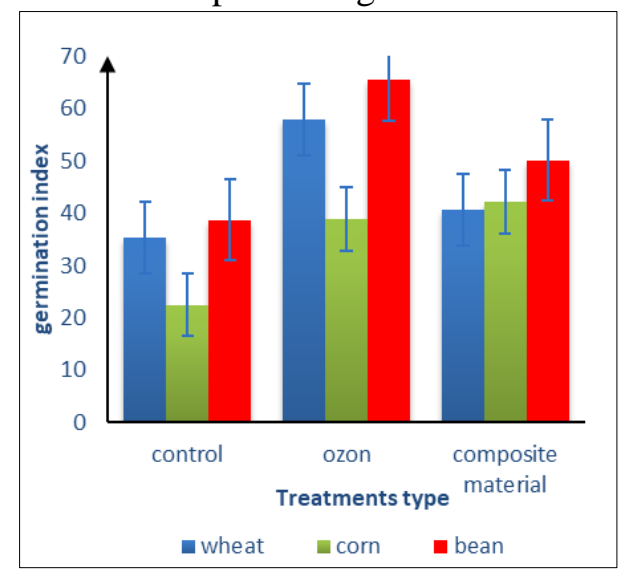

Fig.3. Effect of treatment with ozonated water and composite materials on germination rate index of seeds of Triticum aestivum L., Zea mays L. Phaseolus vulgaris $L$.

A low GRI expresses a low vitality of seed germination. From figure 3 it follows that the lowest GRI value was obtained by corn seeds. Ozone and composite treatment increased the index by $16.9 \%$ and $1.6 \%$, respectively. The highest germination rate index was obtained by beans (65.41) and wheat (57.98), treated with ozone. Compared to ozone, composite materials had a lower impact on the GRI value but, differed considerably from the control batch.

In the research results of the beneficial effects of stimulating agricultural crops by physico-chemical methods, mentioned above, it can be noted that the treatment of seeds with ozonated water and composite materials causes changes in plant metabolism, such as intensification of some physiological processes aimed at shortening the emergence period and increasing the productive potential.

\section{Seedling growth}

The growing conditions were maintained within the temperature limits of $25 \pm 1{ }^{\circ} \mathrm{C}$ and humidity $65 \pm 3 \% \mathrm{HR}$. The horizontal comparator ИЗА - 2 was used to determine the exact height of the plant stem.

Figure 4 represents the growth dynamics of plants Triticum aestivum L., Zea mays L. and Phaseolus vulgaris, depending on the treatment to which they were subjected, for 10 days after sowing.

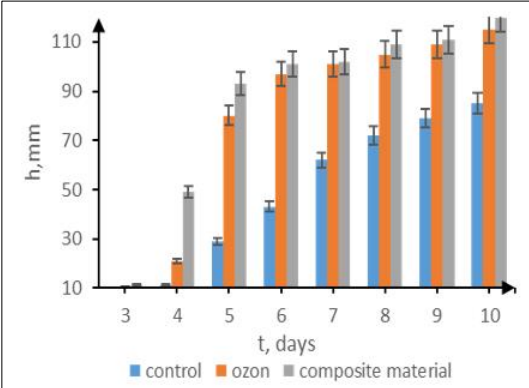

a)

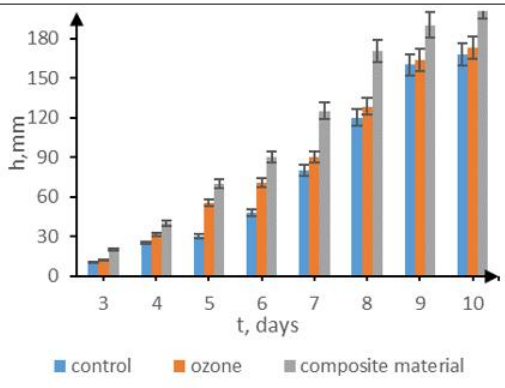

b)

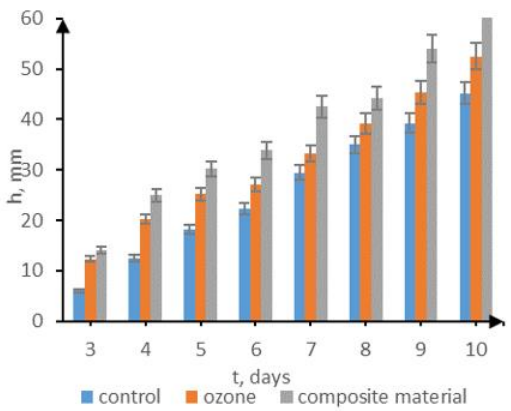

c)
Fig.4. Dynamics of plant growth: a) Triticum aestivum L., b) Zea mays L. and c) Phaseolus vulgaris $\mathrm{L}$, depending on the treatment mode 
Biostimulation with ozone and composite materials is also shown harmoniously on the growth process of the studied plants. As can be seen from the graphs, in the initial stages of the growth of the plants in the control were significantly lagging in development in comparison to those treated, treatment with a biological positive effect, observed along the length of the plant.

The positive effect of applying ozone and composite material on growth is most noticeable in wheat and beans. Thus, on the 10th day of sowing, the height of beans processed with composite material exceeds the growth rate of the control batch by $29.5 \%$, and the one processed with ozonated water-by $18 \%$. The maximum result of $205 \mathrm{~mm}$ of maize plants from the batch processed with composite material differs by $18.46 \%$ more than the control sample and $15.65 \%$ compared to the group processed with ozonated water.

As can be seen from the graph (Fig. 4c) the composite material is the stimulating factor with maximum results recorded from the first stages of plant development. For wheat, the differences are more obvious. The maximum result of $120 \mathrm{~mm}$ of wheat plants from the batch processed with composite material differs by only $41.17 \%$ more than the control sample and only by $4.1 \%$ compared to the batch processed with ozonated water.

\section{Conclusions}

Analyzing the results obtained and the results from the literature for other cultures, we can conclude that ozonated water and composite materials with carbon and clay clusters are able to act as the initiator of the mechanisms of triggering germination and regulate their morpho-physiological processes. Thus, the treatment with composite material of seeds induces the growth rate of plants compared to the control batches for wheat by $41.17 \%$, for corn by $18.46 \%$ and by $29.5 \%$ for beans. In the case of seed, processing with ozonated water, the germination energy increases, and the growth of plants intensifies. The maximum height, measured on the 10th day after sowing, reached the value of $115 \mathrm{~mm}$ for wheat, which exceeds by $26.08 \%$ the growth rate of plants in the control batch. Ozonated water treatment of bean seeds increased the growth rate by $16.19 \%$, but corn did not undergo major changes, exceeding the control batch values by only $2.97 \%$.

Ozonation and composite materials have many advantages and give significant economic effects. The advantages of these technologies are environmentally friendly, have good prospects for development, but require further research to determine the specific parameters for each plant species separately.

\section{References}

1.VASILEVSKI, G., Bulg. J. Plant Physiol., 29, 2003, p. 179.

2.MUSCALU (PLESCAN), O.M., NEDEFF, V., CHITIMUS, A.D., PARTAL, E., MOSNEGUTU, E., RUSU, I.D., Rev.Chim., 69, no. 11, 2018, p. 3106.

3.MUSCALU (PLESCAN), O.M., NEDEFF, V., PARTAL, E., MOSNEGUTU, E., SANDU, I.G., SANDU, I., BARSAN, N., RUSU, D., Rev.Chim., 70, no. 5, 2019, p. 1726.

4.LADJADJIYAN, A., Journal of Environmental Protection and Ecology, 4, no. 1, 2003, p. 662.

5.ALADJADJIYAN, A., Food Production - Approaches, Challenges and Tasks, InTech, Croatia, 2012, p. 146.

6.CHITIMUS, A.D., NEDEFF, V., MOSNEGUTU, E.F., PANAINTE, M., Environmental Engineering and Management Journal, 11, no. 12, p. 2163.

7.MUSCALU (PLESCAN), O.M., NEDEFF, V., CHITIMUS, A.D., PARTAL, E., BARSAN, N., RUSU, I.D., Rev.Chim., 70, vol. 2, 2019, p. 536.

8.CHITIMUS, A.D., RADU, C., NEDEFF, V., MOSNEGUTU, E., BARSAN, N., Scientific Study \& Research Chemistry \& Chemical Engineering, Biotechnology, Food Industry, 17, no. 4, 2016, p. 383.

9.CWINTAL, M., DZIWULSKA-HUNEK, A., WILCZEK, M., International Agrophysics, 24, no. 1, 2010, p. 15.

10.GOUSSOUS, S.J., SAMARAH N. H., ALQUDAH, A. M., OTHMAN, M. O., Experimental Agriculture, 46, no. 2, 2010 p. 231.

11.HERNANDEZ, A.C., DOMINGUEZ, P.A., CRUZ O.A., IVANOV, R., CARBALLO, C.A., ZEPEDA B.R., International Agrophysics, 24, no. 4,2010, p.407.

12.CHITIMUS, A.D., BARSAN, N., NEDEFF, V., MOSNEGUTU, E., MUSCALU (PLESCAN), O., 17th International Multidisciplinary Scientific GeoConference SGEM, 17, vol. 51, 2017, p. 859.

13.RADU, C., CHITIMUS, A.D., TURCU, M., ARDELEANU, G., BELCIU, M., Environmental Engineering and Management Journal, 13, vol. 7, 2014, p. 1687.

14.RADU, C., NEDEFF, V., CHITIMUS, A.D., Journal of Engineering Studies and Research, 19, vol. 2, 2013, p. 89-96.

15.CHITIMUS, A.D., MOSNEGUTU, E.F., NICOLESCU, M.C., TURCU, M., BELCIU, M., ARDELEANU, G., Environmental Engineering and Management Journal, 13, vol. 7, 2014, p. 1581.

16.CHITIMUS, A.D., NEDEFF, V., SANDU, I., RADU, C., MOSNEGUTU, E., SANDU, I.G., BARSAN, N., Rev. Chim. , 70, no. 7, 2019, p. 2545

17.PODLESNY, J., PIETRUSZEWSKI, S., PODLESNA, A., International Agrophysics, 18, 2004, p.65.

18.LOZOVANU, P., MOŞNEAGA, A., LOZOVANU, D., PLUMEE, 3, no.1, 2013, p. 144.

19.CHITIMUS, A.D., NEDEFF, V., SANDU, I., RADU, C., MOSNEGUTU, E., SANDU, I.G., BARSAN, N., Rev.Chim., 70, no. 8, 2019, p. 3058.

20.MUSCALU (PLESCAN), O.M., NEDEFF, F.M., PARTAL, E., MOSNEGUTU, E., PANAINTE-LEHADUS, M., IRIMIA, O., TOMOZEI, C., Scientific Study \& Research Chemistry \& Chemical Engineering, Biotechnology, Food Industry, 20, no. 4, 2019 , p. 585.

21.GOLDAN, E., NEDEFF, V., BARSAN, N., MOSNEGUTU, E., SANDU, A.V., PANAINTE, M., Rev.Chim., 70, no. 3, 2019 , p. 809. 
22.GOLDAN, E., NEDEFF, V., SANDU, I., BARSAN, N., MOSNEGUTU, E., MIRELA PANAINTE, Rev.Chim., 70, no. 6, 2019 , p. 2192. 23.DANIELSSON, H., KARLSSON G.P., Karlsson, P.E., Pleijel, H.H., Atm. Environ., 37, no. 4, 2003, p.475.

24.SIGACIOVA, M.A., PINCIUC, L.G., GRIDINA, S.B., Vestnik AltGAU, 3, 2013, p. 21.

25.POLEVOI, V.V., Plant physiology, (in Russian), V.Sc. Publishing House, Moscow, 1989, p 464.

26.YAKUSHKINA, N.I., Plant physiology, (in Russian), Vlados Publishing House, Moscow, 2005, p.463.

27.IOSOB, G.A., NEDEFF, V., SANDU, I., PRISECARU, M., CRISTEA, T.O., Rev.Chim., 70, no. 4, 2019, p. 1416.

28.MUSCALU (PLESCAN), O.M., NEDEFF, F.M., PARTAL, E., MOSNEGUTU, E., PANAINTE LEHADUS, M., IRIMIA, O., TOMOZEI,

C., Scientific Study \& Research Chemistry \& Chemical Engineering, Biotechnology, Food Industry, 20, no. 4, 2019 , p. 585.

29.CHITIMUS, A.D., NEDEFF, F.M., SANDU, I, RADU, C., BARSAN, N., SANDU, G.I., IRIMIA, O., Rev.Chim., 2019 , 70, no. 12 , p. 4566.

30.CHITIMUS, A.D., NEDEFF, F.M., SANDU, I., RADU, C., MOSNEGUTU, E., BARSAN, N., SANDU, I.G., TOMOZEI, C., Rev.Chim., 70, no. 11, 2019, p. 4035.

31.POLESSKAYA, O.G., Plant cell and reactive oxygen species, (in Russian), Ernakova Publishing House, Moscow, 2007 , p. 140.

32.SHEVCHENKO, A.A., KubGAU, 105, no.01, 2015, p.10.

33.SLOAN, J.J., ENGELKE, M.C., Hort.Technology, 15, no. 1, 2005, p. 148.

34.BASKAKOV, I.V., Procs Voronejskii GAU, 2016, p. 173.

35.GUNTEN, U.V., Water Research, 37, no. 7, 2003, p. 1443.

36.BARBUT, M., MOSNEAGA, A., LOZOVANU, P., PLUMEE, 3, no. 1, 2013, p. 35.

37.LOZOVANU, P., Preparation technology and electrical and optical properties of C60 fullerenes, (in Romanian), CEP, Moldova State University, Chisinau, 1999, p. 18.

38.MOSNEAGA, A., LOZOVANU, P., NEDEFF, V., Cellulose Chem. Technol., 52, no. 7-8, 2018, p. 551.

39.IOSOB, G.A., NEDEFF, V., ION SANDU, CRISTEA T.O., PRISECARU, M., SANDU, I.G., Re. Chim., 70, no. 9, 2019 , p. 3262

40.AL-ANSARI, F., TAOUFIK KSIKS A. The Open Ecology Journal, 9, 2016, p. 13.

41.RANAL, M.A, SANTANA, D.G, FERREIRA, W.R, MENDES, R.O, BRAZ, C., BOT, J., 32, 2009, p. 849.

Manuscript received: 30.01 .2019 